\title{
Effect of stocking rate on milk and pasture productivity and supplementary feed use for spring calving pasture fed dairy systems
}

\author{
D. Patton, ${ }^{*} \dagger$ K. M. Pierce, $\dagger$ and B. Horan ${ }^{* 1}$ \\ *Animal and Grassland Research and Innovation Centre, Teagasc Moorepark, Fermoy, Co. Cork \\ †School of Agriculture and Food Science, University College Dublin, Belfield, Dublin 4, Ireland
}

\begin{abstract}
The productivity of grazing systems is primarily limited by the scale and efficiency of systems applied to the grazable land platform adjacent to the milking parlor. The objective of this study was to compare forage production, utilization and quality, milk production, and requirement for supplementary feeds for 2 different grazing platform stocking rate (GPSR) treatments over $4 \mathrm{yr}$. Animals were randomly allocated to 1 of 2 GPSR treatments: high-closed (HC; 3.1 cows/ha) and high-open (HO; 4.5 cows/ha), which were designed to represent alternative GPSR in a post-European Union milk quota, spring calving, pasture-based milk production system. Animal production data were analyzed using Proc MIXED of SAS with GPSR, year, and parity included as fixed effects in the final model. Within a seasonal spring calving grazing system, at high GPSR and offering moderate amounts of additional supplements based on pasture supply deficits, both systems produced more milk and fat plus protein per hectare in comparison with Irish commercial dairy farms. Although requiring additional supplementation, increased GPSR resulted in increased milk production per hectare but also in an increased requirement for concentrate and forage supplementation during lactation. No significant influence of GPSR was found on body weight and body condition score or reproductive performance during the 4-yr study period. In addition, GPSR also had no effect on pasture production, utilization, or quality during the study period. The strategic use of additional supplements with restricted pasture availability at higher GPSR maintained milk production per cow and significantly increased milk production per hectare.
\end{abstract}

Key words: grazing platform stocking rate, milk production, pasture-based system

Received August 24, 2015.

Accepted March 5, 2016.

${ }^{1}$ Corresponding author: brendan.horan@teagasc.ie

\section{INTRODUCTION}

Temperate grazing systems of production are characterized by a prolonged grazing season $(>275 \mathrm{~d})$ and a predominantly grazed pasture diet (Dillon et al., 2005; Läpple et al., 2012). Such systems, based on a comparably cheap grazed feed source, provide pasture-based milk producers worldwide with a competitive economic advantage over other production systems based on high milk output per hectare with reduced fixed and variable costs (Finneran et al., 2010). Indeed, it is widely acknowledged that the quantity of grazed pasture utilized per hectare is the most important factor influencing operating profit and, therefore, return on capital, on grazing farms (Shalloo et al., 2004; Dillon et al., 2008).

Stocking rate (SR) has been acknowledged as the key factor influencing productivity per hectare on pasturebased dairy farms for many years (Hoden et al., 1991; Macdonald et al., 2008; McCarthy et al., 2011). The aforementioned studies have demonstrated that higher SR result in a reduction in milk production per cow, but an increase in pasture utilization and milk production per hectare (Macdonald et al., 2008; McCarthy et al., 2011). Milk productivity per hectare is the product of SR, expressed as cows per hectare and milk production per cow, and increasing either or both will increase milk production per hectare provided that sufficient feed per hectare is provided (Macdonald et al., 2008).

Many pastureland farms consist of multiple discrete land parcels that are frequently removed from the milking parlor and consequently, cannot be grazed by the dairy herd. In such situations, the productivity of the grazing dairy farm is primarily limited by the scale, and efficiency of systems applied to the grazable land platform adjacent to the milking parlor, whereas the other land parcels are used as young stock rearing and conserved forage production support blocks (O'Donnell et al., 2008; del Corral et al., 2011). Recent studies have acknowledged that, in comparison with grazable area accessible to the milking herd (known as the grazing platform), external land parcels are associated with increased foraging costs, increased management complexity, and reduced farm productivity (del Corral et 
al., 2011). Given such limitations, many studies have highlighted the necessity for pasture-based farmers to develop improved agronomic management practices to increase pasture productivity on each existing hectare of grazing platform (Macdonald et al., 2008; McCarthy et al., 2013). Furthermore, the use of imported supplementary feeds to sustain high animal productivity at high grazing platform SR (GPSR) has recently received more attention (Bargo et al., 2003; Coleman et al., 2010; Fariña et al., 2011). Both Coleman et al. (2010) and Baudracco et al. (2010) suggested that increased supplementation coupled with increased overall SR, can efficiently support high fat plus protein production per cow and per hectare at higher SR while also achieving high levels of pasture utilization compared with lowly supplemented lower SR systems. Equally, however, previous studies have also indicated that the efficiency of pasture utilization and milk production by grazing animals is diminished within systems based on increased supplementation and such systems need careful management to control substitution rates and minimize the decline in pasture utilization (Bargo et al., 2003; Ramsbottom et al., 2015). When supplements are consumed by grazing cows, pasture DM intake is usually reduced due to the partial displacement (substitution) of grazed forage from the diet of supplemented animals (Kellaway and Porta, 1993; Bargo et al., 2003). However, few studies have investigated the effects of increased supplementation of grazing animals on cumulative pasture production, quality, and utilization efficiency within complete farm systems.

Knowledge of the relationship between SR, feed system (FS), and sward productivity is fundamental to the sustainable management of intensified grazing systems. Despite its critical importance, few studies have quantified the biological effectiveness of systems combining increased GPSR with increased supplementation on both milk productivity and pasture utilization efficiency. Consequently, the objective of this study was to compare pasture production, utilization, and quality, milk production per cow and per hectare, and requirement for supplementary feeds for 2 different GPSR treatments within integrated grazing systems over 4 consecutive years.

\section{MATERIALS AND METHODS}

This study was carried out at Ballyhaise College $\left(54^{\circ} 051^{\prime} \mathrm{N}, 07^{\circ} 031^{\prime} \mathrm{W}\right)$ in the Republic of Ireland over a 4-yr period from 2008 to 2011. The experimental site comprises a variety of soil types including alluvial, brown earth, brown podzolic, and gley on a lower Silurian sandstone bedrock. The topography ranges from alluvial flatlands (along the Annalee River, which tran- sects the site) to various shaped, recurrent drumlins with steep slopes $\left(9-18^{\circ}\right)$ and intervening U-shaped valleys.

\section{Animals}

The data presented were collected from $97,110,115$, and 120 animals in 2008, 2009, 2010, and 2011, respectively. During the 4 yr of the study, the experimental herd consisted of Holstein-Friesian (58\%), HolsteinFriesian Jersey crossbred (32\%), and Holstein-Friesian Norwegian Red crossbred animals (10\%), and all animals had received genetic evaluation values using the Irish genetic evaluation system (economic breeding index; EBI). The average overall EBI, milk sub-index, and fertility sub-index of the animals over the period was $€ 103$, €35, and $€ 59$, respectively, during the study period (ICBF, 2009). In yr 1, the experimental animals were assigned to 1 of the 2 GPSR groups before calving based on breed, parity, calving date, previous lactation milk yield, BCS, BW, and EBI. All multiparous animals were subsequently retained on the same GPSR system for the duration of the study. Primiparous animals entering the study were randomly assigned to GPSR treatment based on EBI, breed, calving date, and precalving $\mathrm{BW}$ and $\mathrm{BCS}$.

\section{Feed Systems}

All multiparous animals were randomly allocated to 1 of 2 possible grazing platform pasture-based feed systems (GPFS), namely a high closed feed system (HCFS), which had an overall GPSR of 3.1 cows per hectare, or a high open feed system (HOFS), which had an overall GPSR of 4.5 cows per hectare. The HCFS was designed as a predominantly self-sufficient GPFS based on high levels of pasture utilization and whereby purchased forage and concentrates would not exceed $30 \%$ of total feed requirements. In contrast, the HOFS was created as a high-productivity pasture system to increase milk output per hectare by increasing GPSR and supplementing animals with additional forage and concentrates to meet the additional feed requirements particularly in spring and autumn, corresponding to early and late lactation when pasture growth was reduced. The HOFS was designed to increase productivity on fragmented land holdings where winter feed can be imported from external land parcels. Additional grass silage required for both GPFS was conserved from similar pastures adjacent to the experimental area. The ingredient composition of the concentrate feed $(\mathrm{kg} / \mathrm{t}$ as fed) used was as follows: barley 250, corn gluten 260 , beet pulp 350, soya-bean meal 110 , and minerals plus vitamins 30 . 


\section{Grazing Management}

The experimental area was a permanent grassland site containing greater than $80 \%$ perennial ryegrass (Lolium perenne L.). At the beginning of the farmlet study, a total of 37 paddocks (of on average 0.87 ha) were grouped into 18 sets of 2 (balanced on location, pasture species, topography, and soil type) and randomly assigned to each GPFS. In the first year of the study (2008), 20 paddocks were assigned to the HCFS (15.53 ha) and 13 paddocks were assigned to the HOFS (9.54 ha). During that year, these areas were stocked with 49 and 48 cows on the HCFS and the HOFS, respectively. In the following 3 yr (2009-2011), 3 paddocks were added to the HCFS and 2 to HOFS to allow for herd expansion. During this 3-yr period, the HCFS consisted of 63 cows grazing 20.05 ha and the HOFS consisted of 57 cows grazing 12.63 ha. All paddocks assigned to an individual GPFS at the beginning of the study remained on the same GPFS for the duration of the study. As the herd expanded by $24 \%$ over the period of the study, the average lactation number of the animals used in the study was 2.2 lactations.

Cows were turned out to pasture immediately postpartum (mid-February) and grazed whenever weather conditions allowed, only returning indoors under severe weather conditions. On-off grazing (Kennedy et al., 2009) was used as a management tool to facilitate grazing during periods of inclement weather while reducing pasture damage due to poaching. Weekly grazing management during the first rotation (February 1 to April 1) was based on allocating an equal and increasing proportion of each farmlet to each treatment up to the start of the second rotation. During the main grazing season when actual pregrazing herbage mass in the next grazing paddock exceeded the target level, the paddock was skipped and herbage was harvested as silage (Coleman et al., 2010). Concentrates fed in the milking parlor were used to fill deficits in the feed budget of up to $4 \mathrm{~kg}$ of DM per cow per day during periods when inadequate supplies of pasture were available. Where deficits in excess of $4 \mathrm{~kg}$ of supplement were identified, grass silage was fed in addition to $4 \mathrm{~kg}$ of concentrates to reduce the risks of rumen acidosis arising from high levels of concentrate supplementation on highly digestible pastures (Plaizier et al., 2008). During periods when more than $4 \mathrm{~kg}$ of $\mathrm{DM}$ of silage were required, cows were housed at night and fed pasture only by day. Over the 4 -yr period, average grazing season length (defined as the number of days when grazed pasture was included in the animal diet) was $275 \mathrm{~d}$ extending from early February to mid-November. To reduce feed demand during the autumn when growth rates declined rapidly, cows which failed to conceive during the breeding season were culled from the experimental treatments to extend the grazing season. Once the target closing average farm pasture supply was reached $(550 \mathrm{~kg}$ of $\mathrm{DM} / \mathrm{ha}$ ), all cows were housed full-time and fed grass silage and concentrates. Cows were subsequently dried off in weekly batches based on parity, milk yield, BCS, and expected calving date from early November with all animals dried off by mid-December. The minimum dry period length for all animals was $56 \mathrm{~d}$ and up to $84 \mathrm{~d}$ for thin and primiparous cows. During the dry period, all cows were fed grass silage and a standard dry cow mineral mix from 8 wk prepartum.

Artificial fertilizer application rate was constant for both treatments at $250 \mathrm{~kg}$ of $\mathrm{N}$ per ha per yr (and was applied in 8 equal applications from late-February to mid-September). A rotational grazing system was practiced with the entire area of each farmlet available for grazing in the spring and autumn and growth rates for each week of the year were derived by calculating the net weekly herbage accumulation on ungrazed paddocks. During the main grazing season, both GPFS were managed similarly, on a similar rotation length and grazing similar pregrazing herbage masses. Residency times within paddocks were determined by the achievement of a target postgrazing residual sward height of $4 \mathrm{~cm}$. Silage conservation strategy was adjusted to best suit each GPFS. In the HCFS, the entire area was available for grazing in the spring and autumn. As growth rates increased above demand, a proportion (circa 25\%) of the available area was closed for silage, fertilized and allowed to grow for $8 \mathrm{wk}$ before harvesting. Any further surpluses which arose were removed as bale silage after a 4-wk regrowth period. Because the GPSR was markedly higher in the HOFS, the demand per hectare was always high (in excess of $72 \mathrm{~kg}$ of DM/ha per d), so opportunities to remove silage from the grazing platform area were greatly reduced. Consequently, no fixed area was closed for silage and all surpluses were removed after a 4-wk regrowth period.

\section{Herbage Measurements}

Grazing details were collected on all paddocks during each grazing rotation for 3 of the $4 \mathrm{yr}$ of the study (2009 to 2011 inclusive) and from August 1 onward in 2008. Pregrazing and postgrazing herbage mass (>3.5 $\mathrm{cm}$ horizon) was determined before and after grazing on each paddock for each of the GPSR treatments by harvesting 5 quadrants $(0.5 \mathrm{~m} \times 0.5 \mathrm{~m})$ of pasture using a Gardena hand shears (Accu 60, Gardena International GmbH, Ulm, Germany). The 5 quadrants were spaced equally along the diagonal of each paddock. All mown herbage from each quadrant was collected and weighed, and a subsample was taken and dried for 16 
$\mathrm{h}$ at $90^{\circ} \mathrm{C}$ for $\mathrm{DM}$ determination. The average paddock pregrazing and postgrazing herbage mass above a cutting height of $3.5 \mathrm{~cm}$ was then calculated. Pregrazing and postgrazing sward heights were also determined on each paddock before and after grazing by taking between 30 and 50 measurements across the diagonal of the paddock using a folding pasture plate meter with a steel plate (Jenquip, Feilding, New Zealand).

Herbage disappearance was also calculated based on the following formula:

herbage disappeared $=$ (pregrazing herbage mass

- postgrazing herbage mass); $\mathrm{kg}$ of DM/ha.

Grazing efficiency was subsequently calculated for each paddock based on the formula:

$$
\begin{gathered}
\text { grazing efficiency }=(\text { herbage disappeared } / \\
\text { pregrazing herbage mass }) \times 100, \%
\end{gathered}
$$

Daily herbage allowance and daily herbage disappeared were also calculated based on the residency time within each paddock. Grazing data were analyzed for 3 periods of the grazing season: spring (turnout to April 15), midseason (April 15 to July 31), and autumn (August 1 to November 15) corresponding to early and late lactation where the demand for pasture exceeds supply and mid-lactation where pasture supply exceeds demand. Total annual pasture production for each farmlet was calculated using the methodology outlined previously by McCarthy et al. (2013). Silage intakes were measured on a weekly feed budget basis where daily silage allocated to dry cows and milking cows were weighed separately and recorded for each group.

\section{Chemical Analyses}

Herbage samples were collected from each paddock for each GPSR and were dried at $40^{\circ} \mathrm{C}$ for $48 \mathrm{~h}$ and milled through a 1-mm sieve. Samples were bulked by FS by week and analyzed for DM, ash, ADF, NDF (Van Soest, 1963), CP (Leco FP-428; Leco Australia Pty Ltd., Baulkham Hills, New South Wales, Australia), and OM digestibility (Morgan et al., 1989). Samples collected for chemical analysis were bulked for each experimental week and analyzed for DM content, ash, ADF, and NDF (Ankom Technology, Macedon, NY), OM digestibility (Fibered Systems, Foss, Ball mount, Dublin, Ireland), and CP (Leco FP-428, Leco Australia Pty Ltd.). Concentrate samples were collected on a weekly basis. These samples were then bulked for each month and were analyzed for DM, ash, CP, NDF, and crude fiber. Silage samples were collected twice weekly and bulked for each experimental week. Silage samples were analyzed for DM, ash, CP, NDF, and ADF.

\section{Animal Measurements}

Cows were milked at 0700 and 1530 h daily throughout lactation in all $4 \mathrm{yr}$ of the study. Weekly milk production was derived from individual milk yields $(\mathrm{kg})$ recorded at each milking. Milk fat, protein, and lactose concentrations were determined weekly from one successive evening and morning milking sample from each cow using a Milkoscan 203 (DK-3400, Foss Electric, Hillerød, Denmark). Weekly fat plus protein and SCM (Tyrrell and Reid, 1965) yields were also calculated. Milk, fat, protein, lactose, and fat plus protein yield per hectare (from the grazing area) were calculated by multiplying total milk and fat plus protein production per cow by the GPSR of each treatment to give the yield per hectare.

Individual animal BW was recorded weekly upon exit from the milking parlor using an electronic scale (Tru-Test Ltd., Auckland, New Zealand). In addition, BCS was assessed every $3 \mathrm{wk}$ by the same individual throughout the study on a scale of 1 to 5 in increments of 0.25 as outlined by Edmonson et al. (1989). Body weight and BCS variables analyzed were BW and BCS at calving, nadir, and at the end of lactation. Body weight and BCS change from calving to nadir and from nadir to the end of lactation were also analyzed. Reproductive measurements calculated and analyzed were 24-d submission rate (calculated based on an animal being served within the first $24 \mathrm{~d}$ of the breeding season irrespective of calving date), calving to first service interval (interval in days from calving to first service), calving to conception interval (interval in days from calving to conception), conception rate to first service (pregnant to first service and pregnant at the end of the breeding season), pregnancy rate after the first 42 $\mathrm{d}$ of the breeding season (pregnant at d 42 of breeding season and pregnant at the end of the 13-wk breeding season), and overall pregnancy rate (confirmed by ultrasound scanning $150 \mathrm{~d}$ after the start of the breeding season). All incidences of lameness, mastitis, and calving difficulty were recorded in a database as they occurred. Somatic cell count was determined from consecutive morning and evening milkings once weekly from individual cows. The SCC was recorded using a flow cytometer (Bentley 3000, Bentley Instruments Inc., Chaska, MN).

All cows were examined before breeding start date using transrectal ultrasound imaging (Aloka SDD 500 $\mathrm{V}$ scanner with a 5-MHz transducer, Aloka Ltd., To- 
kyo, Japan) to assess the degree of uterine involution and to detect ovarian or uterine disorders. The incidence of reproductive disorders (such as endometritis, pyometra, ovarian cysts, or exhibiting no resumption of ovarian activity) was recorded. Anovulatory anestrous cows were treated with the following protocol: injection (i.m.) of GnRH [0.01 mg of Buserelin (Receptal), Intervet, Dublin] and insertion of an intravaginal progesterone releasing device (Eazi-breed CIDR containing $1.38 \mathrm{~g}$ of P4, Pfizer Animal Health, Dublin, Ireland). Seven days later, each cow received an injection (i.m.) of $\mathrm{PGF}_{2 \alpha}$ (Lutylase, Pfizer Animal Health), and the following day the CIDR was removed. Ovulation was induced by administering GnRH $36 \mathrm{~h}$ after CIDR withdrawal. Breeding commenced on May 5 for both FS. Cows were visually observed for estrus at least 4 times daily for the duration of the breeding season. Tail paint was used as a heat detection aid and was reapplied when necessary. Artificial insemination was used for the first $8 \mathrm{wk}$ of the breeding season, and bulls were introduced for the remaining 5 wk. Cows displaying estrus were inseminated by the same technician during each year of the study. Cows detected in estrus at morning milking were inseminated that morning, whereas cows detected later that day were inseminated the following morning. All cows were inseminated with thawed-frozen semen, the quality of which had been verified before the start of the breeding season. Pregnancy diagnosis was performed by transrectal ultrasound imaging $150 \mathrm{~d}$ after the beginning of the breeding season to determine overall pregnancy rates.

\section{Statistical Analysis}

The effects of GPFS on total lactation yields for milk and fat plus protein, milk composition, calving to first service interval, and calving to conception interval were determined using mixed models (Proc Mixed; SAS Institute Inc., 2006) with cow included as a repeated effect to account for the repeated lactations per cow; a compound symmetry covariance structure with heterogeneous variances provided the best fit to the data. Initial models included the effects for GPFS, parity, year, breed, calving date, and interactions. Nonsignificant effects $(P>0.05)$ were removed from the models by backward elimination. Number of services per cow was analyzed using the Kruskal-Wallis nonparametric test (PROC NPAR1WAY, SAS Institute Inc., 2006). Binary data (pregnancy rate to first and second service, 42-d pregnancy rate, submission rate, and overall pregnancy rates) were analyzed using chi-squared analysis (PROC FREQ, SAS Institute Inc., 2006) over the 4 yr of the project.
The effects of GPFS and year on daily herbage allowance, total feed allowance, and postgrazing height was determined using mixed models (Proc Mixed, SAS Institute Inc., 2006) with rotation included as a repeated effect. A compound symmetry covariance structure provided the best fit to the data. The effects of FS on BW, BCS, calving to first service interval, and calving to conception interval were analyzed using general linear models (Proc GLM, SAS Institute Inc., 2006), and the effects of FS, year, parity, breed, and their interactions were included in the model.

\section{RESULTS}

\section{Climate and Pasture Production}

Monthly rainfall and temperature data for the 4-yr study period and for the 10-yr average (2001 -2011) are presented in Table 1. Average annual rainfall and mean temperature at the site over the 4 yr from 2008 to $2011\left(1,046 \mathrm{~mm}\right.$ and $9^{\circ} \mathrm{C}$, respectively) were very similar to the $10-\mathrm{yr}$ average $\left(1,019 \mathrm{~mm}\right.$ and $9.1^{\circ} \mathrm{C}$, respectively). On average over the 4 yr, November had the greatest rainfall $(128 \mathrm{~mm})$, whereas June had the lowest rainfall $(55 \mathrm{~mm})$. Additionally, December was the coldest month (average mean temperature of $2.5^{\circ} \mathrm{C}$ ), whereas July was warmest (average mean temperature of $\left.14.8^{\circ} \mathrm{C}\right)$.

Average annual net herbage production was 13,225 $(\mathrm{SEM}=542) \mathrm{kg}$ of DM per ha during the 4-yr study period (Figure 1) and was unaffected by GPFS $(P=$ 0.394). Year had a significant effect on annual herbage production $(P=0.001)$, and was least in 2008 and greatest in 2011 (11,647 and 15,472 $\mathrm{kg}$ of DM per ha, respectively). On average over the study period, average daily growth rate ( $\mathrm{kg}$ of DM per ha per day) exceeded daily herd demand for $192 \mathrm{~d}$ for HCFS compared with $130 \mathrm{~d}$ for HOFS.

\section{Grazing Characteristics and Feed Inputs}

The effect of GPFS on grazing characteristics and sward quality is presented in Table 2. As the grazing management decision rules were the same for both GPFS during the main grazing season (April to $\mathrm{Au}-$ gust), the grazing year has been broken into 3 distinct periods for analysis: spring (turnout to pasture in early February until the end of the first rotation in April), midseason (from the beginning of the second rotation in mid-April until late July), and autumn (from the start of August until the end of the grazing season in mid-November). Over the entire grazing season, pregrazing herbage mass $(P<0.05)$ was higher for HCFS 
Table 1. Temperature $\left({ }^{\circ} \mathrm{C}\right)$ and rainfall $(\mathrm{mm})$ data for each month during 2008 to 2011 compared with the previous 10 -yr period

\begin{tabular}{|c|c|c|c|c|}
\hline \multirow[b]{2}{*}{ Month } & \multicolumn{2}{|c|}{ Rainfall } & \multicolumn{2}{|c|}{ Mean temperature } \\
\hline & 2008-2011 & $10 \mathrm{yr}$ average & 2008-2011 & $10 \mathrm{yr}$ average \\
\hline January & 97 & 85 & 3.4 & 4.4 \\
\hline February & 55 & 68 & 4.8 & 5.1 \\
\hline March & 73 & 67 & 5.8 & 5.9 \\
\hline April & 70 & 69 & 8.9 & 8.4 \\
\hline May & 62 & 75 & 11.1 & 11.2 \\
\hline June & 54 & 63 & 13.5 & 13.5 \\
\hline July & 92 & 77 & 14.8 & 14.6 \\
\hline August & 118 & 112 & 14.0 & 14.2 \\
\hline September & 106 & 102 & 12.7 & 12.8 \\
\hline October & 116 & 120 & 9.9 & 9.4 \\
\hline November & 128 & 119 & 6.7 & 6.9 \\
\hline December & 71 & 56 & 2.5 & 3.4 \\
\hline Annual & 1,046 & 1,019 & 9 & 8.3 \\
\hline
\end{tabular}

compared with HOFS (1,390 and 1,246 kg of DM/ ha, respectively), whereas postgrazing residual sward height and grazing efficiency were similar for both FS (38.2 $\mathrm{mm}$ and $97.2 \%$, respectively). Similarly, herbage disappearance tended to be higher $(P<0.07)$ for HCFS compared with HOFS (1,324 and 1,254 kg of DM/ha, respectively). A significant GPFS by season interaction was found for herbage disappearance $(P<0.04)$ due to the comparably increased herbage disappearance for HCFS compared with HOFS during autumn (1,586 vs. $1,417 \mathrm{~kg}$ of $\mathrm{DM} / \mathrm{ha})$. No significant differences were found in sward CP or OM digestibility between FS. Season had a significant effect on grazing parameters with the exception of sward CP content. Pregrazing herbage mass, postgrazing residual sward height, and herbage disappearance were least in spring (941 kg of

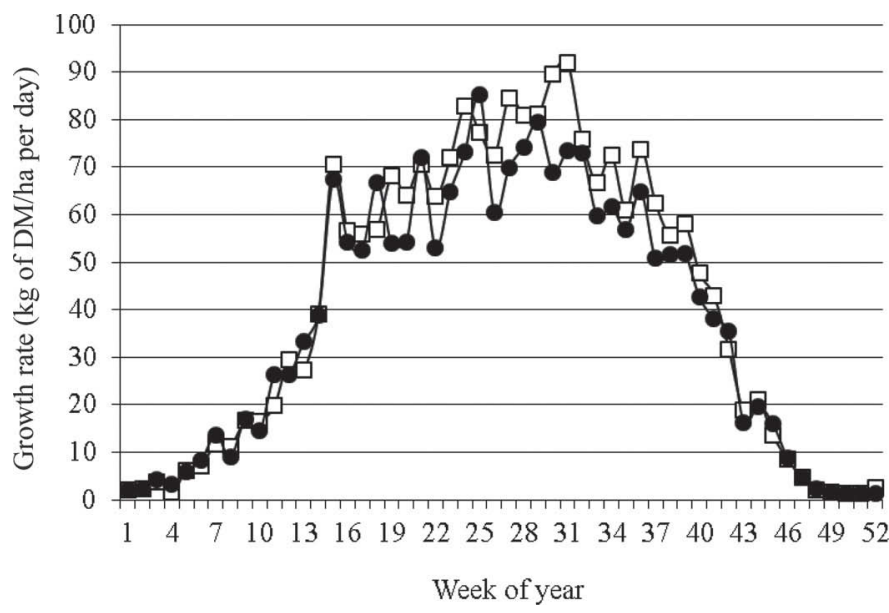

Figure 1. Effect of grazing platform feed system [high closed $(\mathrm{HCFS})=3.1$ cows $/$ ha, $\bullet$; and high open $(\mathrm{HOFS})=4.5$ cows $/$ ha, $\square]$ on pasture growth during the 4-yr study.
$\mathrm{DM} / \mathrm{ha}, 35.7 \mathrm{~mm}$, and 1,069 $\mathrm{kg}$ of $\mathrm{DM} / \mathrm{ha})$, greatest in autumn $(1,581 \mathrm{~kg}$ of DM/ha, $39.1 \mathrm{~mm}$, and $1,501 \mathrm{~kg}$ of $\mathrm{DM} / \mathrm{ha})$, and intermediate during mid-season $(1,433 \mathrm{~kg}$ of DM/ha, $38.8 \mathrm{~mm}$, and 1,297 kg of DM/ha), whereas grazing efficiency was greater in spring $(102.2 \%)$ compared with mid-season and autumn (94.5\%) due to the increased grazing severity achieved during spring. Sward OM digestibility content was greatest in spring $(827.4 \mathrm{~g} / \mathrm{kg})$, intermediate in mid-season $(817.3 \mathrm{~g} / \mathrm{kg})$, and least during autumn $(800.3 \mathrm{~g} / \mathrm{kg})$. No GPSR or seasonal differences were observed in silage or concentrate quality. The chemical composition of grass silage (71, 144, 548, and $329 \mathrm{~g} / \mathrm{kg}$ for ash, CP, NDF, and $\mathrm{ADF}$, respectively) and concentrate $(97,152,319$, and $174 \mathrm{~g} / \mathrm{kg}$ for ash, $\mathrm{CP}, \mathrm{NDF}$, and crude fiber, respectively) was similar to previous studies (Coleman et al., 2010; McCarthy et al., 2013).

The effect of GPFS on herbage utilization and concentrate and silage supplementation requirements during the 4-yr study period are presented in Table 3 and Figure 2. No significant difference was found in total herbage utilization $(9,972 \mathrm{~kg}$ of DM/ha) or in the grazed herbage utilization between GPFS $(8,792 \mathrm{~kg}$ of $\mathrm{DM} / \mathrm{ha}$ ); however, more herbage was harvested as silage within the HCFS farmlet (1,704 vs. $644 \mathrm{~kg}$ of $\mathrm{DM} /$ ha per yr for HOFS). Consequently, and although the HCFS was designed as a predominantly enclosed GPFS wherein, the majority of the feed required would be harvested within the farmlet area, lower than anticipated average pasture growth during the $4 \mathrm{yr}$ of the study necessitated that $1,704 \mathrm{~kg}$ of $\mathrm{DM} / \mathrm{ha}$ (or $550 \mathrm{~kg}$ of DM/cow) of forage were imported as winter feed from outside the HCFS farmlet to meet the feed requirements of this treatment. In comparison, 3,924 $\mathrm{kg}$ of DM/ha (or 1,288 $\mathrm{kg}$ of DM/cow) of winter forage was imported from outside the HOFS treatment area. 
Table 2. The effect of grazing platform feed system ${ }^{1}$ (GPFS) and season $^{2}$ (S) on grazing characteristics and sward quality during the 4-yr study (2008-2011)

\begin{tabular}{|c|c|c|c|c|c|c|}
\hline \multirow[b]{2}{*}{ Item } & \multicolumn{2}{|c|}{ GPFS } & \multirow[b]{2}{*}{ SEM } & \multicolumn{3}{|c|}{$P$-value } \\
\hline & HCFS & HOFS & & GPFS & $\mathrm{S}$ & GPFS*S \\
\hline Spring & 950 & 932 & & & & \\
\hline Mid-season & 1,539 & 1,324 & & & & \\
\hline Autumn & 1,683 & 1,480 & & & & \\
\hline Postgrazing residual herbage height, $\mathrm{mm}$ & 38.7 & 37.7 & 0.34 & 0.46 & 0.001 & 0.11 \\
\hline Autumn & 39.7 & 38.5 & & & & \\
\hline Herbage disappeared, ${ }^{3} \mathrm{~kg}$ of DM/ha & 1,324 & 1,254 & 41.5 & 0.07 & 0.001 & 0.04 \\
\hline Spring & 1,080 & 1,058 & & & & \\
\hline Mid-season & 1,307 & 1,287 & & & & \\
\hline Autumn & 1,586 & 1,417 & & & & \\
\hline $\mathrm{CP}$ content, $\mathrm{g} / \mathrm{kg}$ & 236.6 & 226.9 & 9.87 & 0.28 & 0.66 & 0.97 \\
\hline Spring & 243.7 & 232.0 & & & & \\
\hline Autumn & 800.5 & 800.2 & & & & \\
\hline
\end{tabular}

${ }^{1}$ Grazing platform stocking rate: high closed (HCFS) $=3.1$ cows $/$ ha, high open $($ HOFS $)=4.5$ cows $/$ ha.

${ }^{2}$ Season: spring (January-March), mid-season (April-July), autumn (August-November).

${ }^{3}$ Herbage disappeared $(\mathrm{kg}$ of $\mathrm{DM} / \mathrm{ha})=$ (pregrazing herbage mass - postgrazing herbage mass).

Concentrate and silage supplementation also varied significantly between GPFS during lactation. The HOFS received more concentrate and silage $(872$ and $634 \mathrm{~kg}$ of $\mathrm{DM} /$ cow, respectively) during lactation compared with HCFS (551 and $360 \mathrm{~kg}$ of DM/cow, respectively). Based on the feed requirements, each GPFS was also defined in terms of comparative stocking rate (CSR; Macdonald et al., 2008) incorporating both animal size, level of supplementation and herbage productivity as an alternative measure of GPSR. The CSR was $90 \mathrm{~kg}$ of BW/tonne of DM available for both the HCFS and HOFS treatments.

Table 3. Effect of grazing platform feed system ${ }^{1}$ on animal diet and supplementary feed requirements

\begin{tabular}{lrr}
\hline Feed system & HCFS & HOFS \\
\hline Lactating cow diet, kg of DM/cow & & \\
Grazed pasture & 2,724 & 2,031 \\
Concentrate & 551 & 872 \\
$\quad$ Grass silage & 360 & 634 \\
Nonlactating cow diet, kg of DM/cow & 808 & 797 \\
$\quad$ Grass silage & & \\
Feed utilized, kg of DM/ha per yr & 8,445 & 9,139 \\
Grazed pasture & 1,704 & 644 \\
Grass silage produced & 1,917 & 5,796 \\
Grass silage imported & 1,708 & 3,924 \\
Concentrates imported &
\end{tabular}

${ }^{1}$ Grazing platform feed system: high closed (HCFS) $=3.1$ cows $/$ ha, high open $(\mathrm{HOFS})=4.5$ cows $/$ ha.

\section{Milk Production, BW, BCS, and Reproductive Performance}

The effect of FS on total lactation milk production and composition over the 4 -yr study period is shown in Table 4 and Figures 3 and 4. Average lactation length was similar for both GPFS ( $270 \mathrm{~d})$. The HOFS produced more milk $(4,865 \mathrm{~kg}), \mathrm{SCM}(4,948 \mathrm{~kg})$, and milk solids $(390 \mathrm{~kg})$ per cow compared with HCFS $(4,648,4,756$, and $377 \mathrm{~kg}$, respectively), whereas the persistency of lactation was similar for both FS (Figure 3). Milk fat and lactose content were unaffected by GPFS (45.7 and $47.4 \mathrm{~g} / \mathrm{kg}$, respectively); however, milk protein content was significantly higher $(P<0.001)$ for HCFS $(35.7 \mathrm{~g} /$ $\mathrm{kg})$ compared with HOFS $(35.0 \mathrm{~g} / \mathrm{kg})$. At the system level, milk and milk solids yield per hectare of milking platform were significantly higher $(P<0.001)$ for HOFS (22,229 and $1,786 \mathrm{~kg}$, respectively) compared with HCFS (14,190 and 1,153 kg, respectively; Figure 4).

Feed system had no significant effect on BW and BCS during lactation (Table 5, Figure 5). No significant effect of GPFS, interaction between breed group and GPFS, or interaction between GPFS and parity was observed for any of the reproductive variables measured over the 4-yr study period, and therefore only the main effects of GPFS are shown (Table 5). The average intervals from calving to first service and from calving to conception were 75 and $100 \mathrm{~d}$, respectively. 
a)

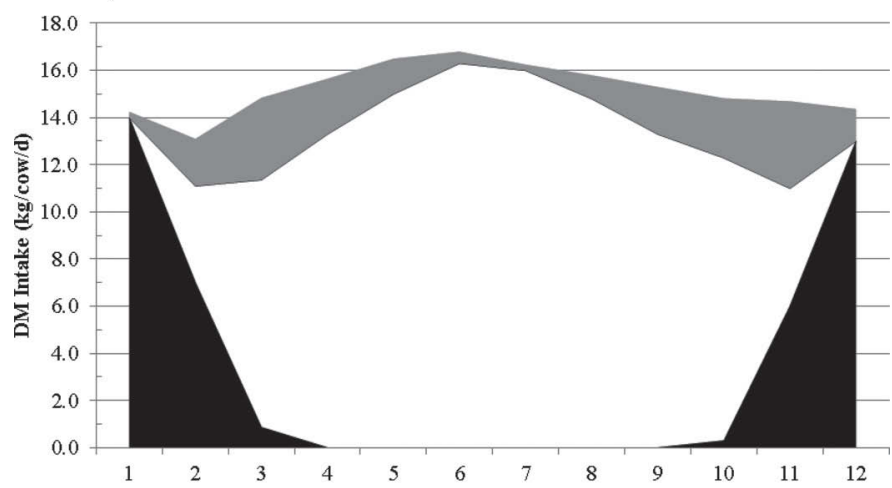

b)

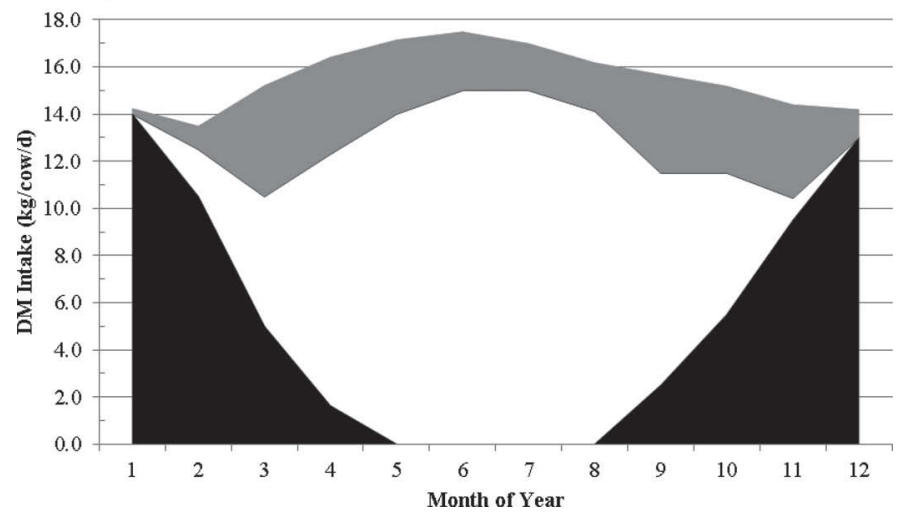

Figure 2. Effect of grazing platform feed system $[\mathrm{a}=$ high closed $($ HCFS $)=3.1$ cows $/$ ha; and $\mathrm{b}=$ high open $(\mathrm{HOFS})=4.5 \mathrm{cows} / \mathrm{ha}]$ on dietary intake ( $\mathrm{kg}$ of $\mathrm{DM} /$ cow per d) during lactation (silage, black shading; concentrate, gray shading; and pasture, white area).

Similarly, no significant differences were found between FS in the number of services received per cow (1.8), the submission rate during the first $24 \mathrm{~d}$ of the breeding period $(83 \%)$, the conception rate to first service $(41 \%)$, the 6 -wk pregnancy rate $(57 \%)$, or the overall 13 -wk pregnancy rate $(80 \%)$. a)

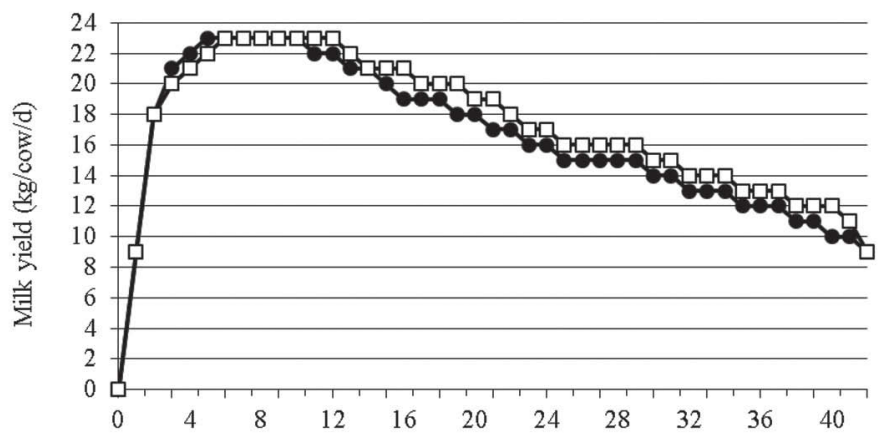

b)

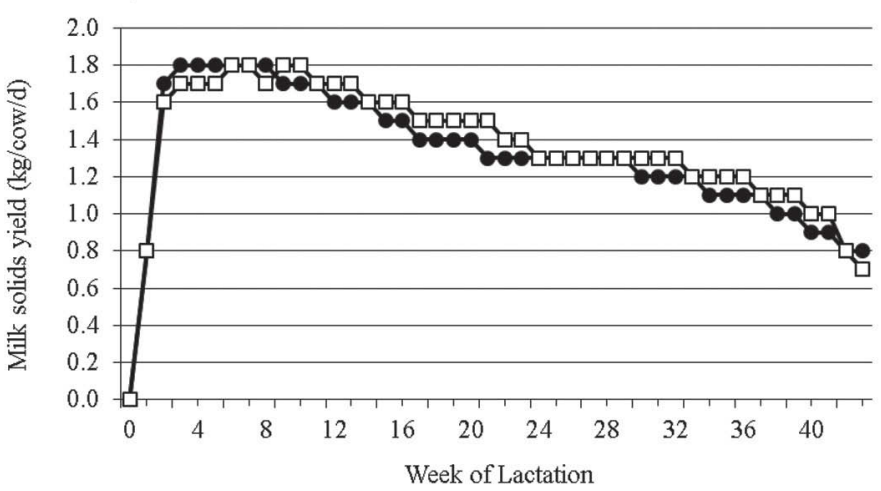

Figure 3. The effect of grazing platform feed system [high closed $($ HCFS $)=3.1$ cows $/$ ha, $\bullet$; and high open $($ HOFS $)=4.5$ cows $/$ ha, $\square]$ on a) daily milk yield ( $\mathrm{kg} / \mathrm{cow}$ per $\mathrm{d}$ ) and b) daily milk solids (milk fat plus protein) yield (kg of milk solids/cow/d) for each week of lactation.

\section{DISCUSSION}

Traditional pasture-based milk production systems are based on a medium overall farm SR (2 to 3 livestock units/ha) and based on high mid-season pasture growth, which exceeds animal requirements (Dillon et al., 2005). In such systems, both the lactation and total winter

Table 4. Effect of grazing platform feed system ${ }^{1}$ on total lactation milk production and composition

\begin{tabular}{|c|c|c|c|c|}
\hline Item & HCFS & HOFS & SEM & $P$-value \\
\hline \multicolumn{5}{|c|}{ Individual animal performance } \\
\hline Lactation length, $\mathrm{d}$ & 269 & 271 & 6.3 & 0.54 \\
\hline Milk yield, kg/cow & 4,648 & 4,865 & 53.4 & 0.002 \\
\hline SCM yield, $\mathrm{kg} / \mathrm{cow}$ & 4,756 & 4,948 & 53.3 & 0.007 \\
\hline Fat plus protein yield, kg & 377 & 390 & 4.3 & 0.02 \\
\hline \multicolumn{5}{|l|}{ Milk constituent, g/kg } \\
\hline Fat & 45.6 & 45.8 & 0.4 & 0.65 \\
\hline Protein & 35.7 & 35.0 & 0.15 & 0.001 \\
\hline Lactose & 47.3 & 47.5 & 0.09 & 0.07 \\
\hline \multicolumn{5}{|l|}{ System performance } \\
\hline Milk yield, $\mathrm{kg} / \mathrm{ha}$ & 14,190 & 22,229 & 208.4 & 0.001 \\
\hline Fat plus protein, $\mathrm{kg} / \mathrm{ha}$ & 1,153 & 1,786 & 17.2 & 0.001 \\
\hline
\end{tabular}

${ }^{1}$ Grazing platform feed system: high closed $(\mathrm{HCFS})=3.1 \mathrm{cows} / \mathrm{ha}$, high open $(\mathrm{HOFS})=4.5$ cows $/$ ha 
Table 5. Effect of grazing platform feed system $^{1}$ on reproductive performance, BW, and BCS

\begin{tabular}{|c|c|c|c|c|}
\hline Reproductive performance & HCFS & HOFS & SEM & $P$-value \\
\hline Calving to service interval, $\mathrm{d}$ & 75 & 75 & 1.0 & 0.84 \\
\hline Calving to conception interval, $\mathrm{d}$ & 100 & 99 & 2.3 & 0.72 \\
\hline Services per cow, no. & 1.8 & 1.8 & 0.07 & 0.80 \\
\hline 24 -d submission rate, $\%$ & 81 & 85 & & 0.19 \\
\hline Conception rate to first service, $\%$ & 38 & 43 & & 0.26 \\
\hline 6 -wk pregnancy rate, $\%$ & 56 & 58 & & 0.81 \\
\hline Overall pregnancy rate, $\%$ & 79 & 81 & & 0.50 \\
\hline BW at calving, kg & 501 & 497 & 6.2 & 0.62 \\
\hline Nadir BW, kg & 448 & 458 & 5.6 & 0.19 \\
\hline $\mathrm{BW}$ at the end of lactation, $\mathrm{kg}$ & 519 & 512 & 5.3 & 0.27 \\
\hline BCS at calving & 3.12 & 3.14 & 0.024 & 0.54 \\
\hline Nadir BCS & 2.81 & 2.81 & 0.033 & 0.90 \\
\hline BCS at the end of lactation & 2.89 & 2.94 & 0.020 & 0.12 \\
\hline
\end{tabular}

${ }^{1}$ Grazing platform feed system: high closed (HCFS) $=3.1$ cows $/$ ha, high open $($ HOFS $)=4.5$ cows $/$ ha.

feed requirements of the herd are produced from the grazable farm area (Dillon et al., 1995; McCarthy et al., 2011). The dominant effect of increasing SR on grazed pasture utilization and milk production per hectare has been widely reported, albeit with lowered levels of milk production per cow (Macdonald et al., 2008; McCarthy et al., 2011). The HCFS treatment represents the control GPSR and was chosen as a normal but intensive

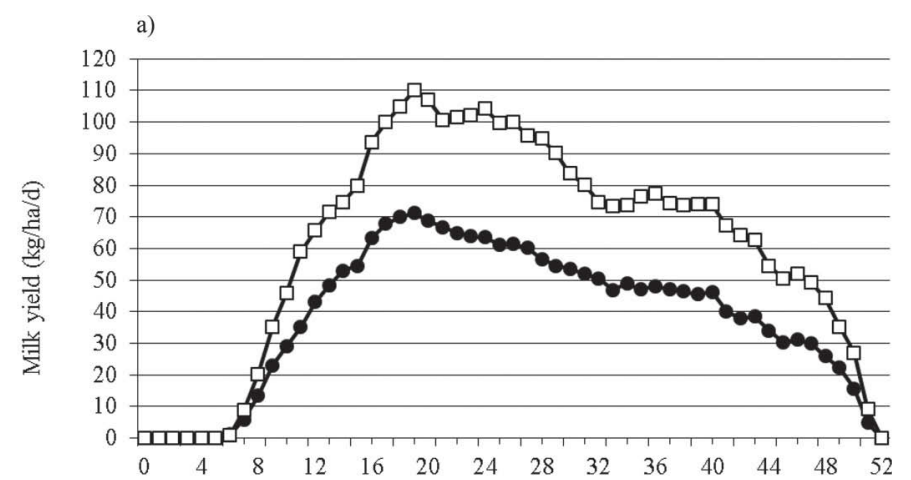

b)

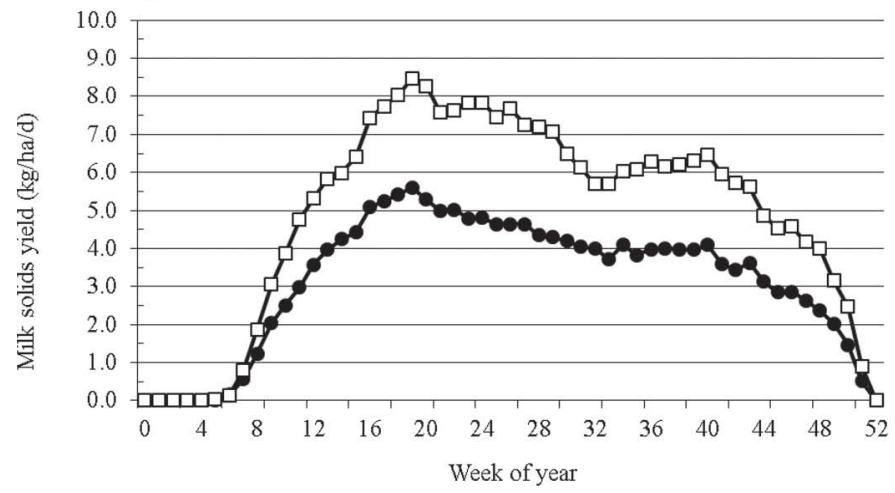

Figure 4. The effect of grazing platform feed system [high closed $(\mathrm{HCFS})=3.1 \mathrm{cows} / \mathrm{ha}, \bullet$; and high open $(\mathrm{HOFS})=4.5$ cows $/$ ha, $\square]$ on (a) daily milk yield ( $\mathrm{kg} / \mathrm{ha}$ per $\mathrm{d}$ ) and (b) daily milk solids (milk fat plus protein) yield $(\mathrm{kg} / \mathrm{ha} / \mathrm{d})$ for each week of year.
GPSR recommended to commercial pasture-based milk producers and used within research trials (Horan et al., 2004; Macdonald et al., 2008; McCarthy et al., 2013). The HOFS was designed to quantify the biological effect of significantly increasing GPSR to maximize milk production and pasture utilization on the grazable area and to acquire the additional spring, autumn, and winter feed requirements for the herd from outside the grazable area. The intensity of both FS within the cur-

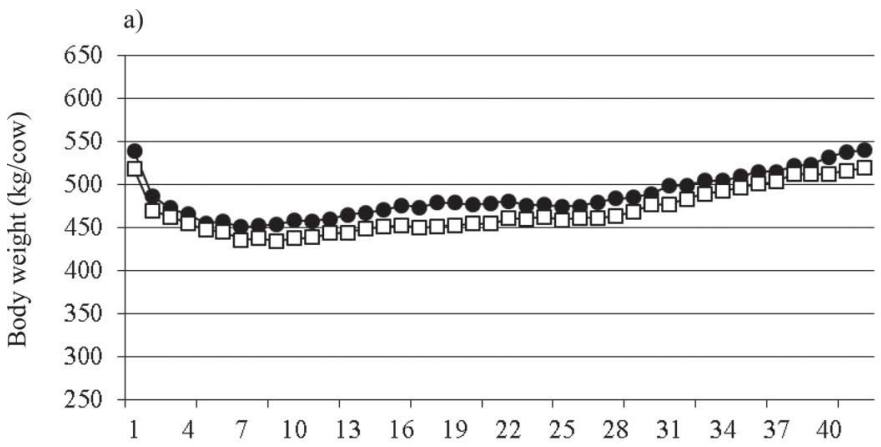

b)

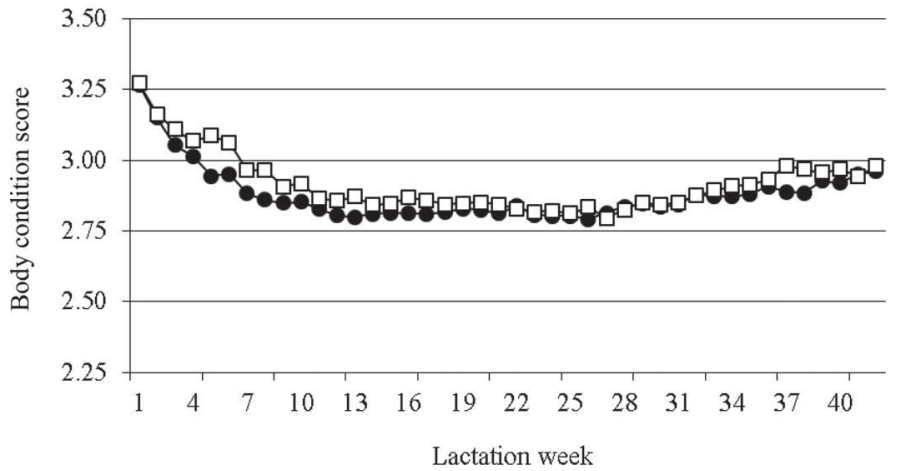

Figure 5. The effect of grazing platform feed system [high closed $(\mathrm{HCFS})=3.1 \mathrm{cows} / \mathrm{ha}, \bullet$; and high open $(\mathrm{HOFS})=4.5 \mathrm{cows} / \mathrm{ha}, \square]$ on (a) BW and (b) BCS per week of lactation. 
rent experiment is exemplified by the high CSR of both FS, which is indicative of optimally designed systems in terms of feed inputs vis a vis animal requirements (Macdonald et al., 2008). The average amount of herbage used (10.0 t of DM/ha) and milk production per hectare $(14,190$ and $22,229 \mathrm{~kg}$ of milk/ha for HG and HOFS, respectively) in this study is well above that normally achieved on commercial dairy farms (7.1 t of $\mathrm{DM} / \mathrm{ha}$ and $9,120 \mathrm{~kg}$ milk/ha at a mean GPSR of 1.8 to 1.9 livestock units/ha; Dillon et al., 2005; Creighton et al., 2011; NFS, 2014) and is indicative of the potential productivity of intensified grazing systems.

Experiments using SR as the main variable are difficult to interpret because of the important effect of experimental decision rules. Previous studies have reported inconsistent effects of SR on pasture accumulation and utilization. The lack of an effect of SR on net herbage accumulation and total utilization has been reported in several recent experiments using similar measurement methodologies (Valentine et al., 2009; Fariña et al., 2011; both of these studies were undertaken in Australia with a range of SR from 2.5 to 7.4 cows/ha with varying levels of supplementary feed). Although beneficial effects of increasing SR on net herbage production, grazed pasture utilization, and feed quality have also been reported in the literature (Hoden et al., 1991; Macdonald et al., 2008; McCarthy et al., 2013), increasing SR is frequently associated with changes in rotation lengths, grazing severities, and feed allocation rates, which independently influence forage growth, utilization, and quality (Bargo et al., 2003; Lee et al., 2007; Sollenberger and Vanzant, 2011). In contrast, this experiment was designed to impose similar grazing management in both GPSR treatments, and accordingly no significant differences in pasture production, quality, and utilization were observed. Similarly, several other recent SR experiments using similar measurement methodologies have also observed no effect of SR on pasture productivity, herbage utilization, or sward quality (Valentine et al., 2009; Fariña et al., 2011).

The higher total lactation milk, SCM, and fat plus protein yield achieved with the HOFS group is expected given the large increase in energy supply with this FS. This is consistent with previous studies, which showed that total DMI increased with increasing proportion of concentrate in the diet (Bargo et al., 2003). The decline in milk protein content observed with the HOFS also agrees with previous findings (Horan et al., 2004) and can be attributed to the increased conserved grass silage content and reduced grazed grass content of the HOFS lactation diet. Stocking rate treatment had no effect on BW and BCS characteristics or on the reproductive parameters measured in this study, which is indicative of both the similarity and adequacy of feed supply to animals in both systems examined. The overall similarity in BW, BCS, and reproductive performance between GPSR treatments in this study is also consistent with previous studies (Horan et al., 2004; Macdonald et al., 2008; Patton et al., 2012).

The provision of adequate amounts of winter feed is a key requirement of Irish pasture-based production systems. Although the quantity of silage produced was higher for HCFS compared with HOFS (1,704 and 644 $\mathrm{kg}$ of DM/ha, respectively), the lower than anticipated annual growth during the study resulted in reduced conserved forage production and an increased lactation requirement for silage supplements. Consequently, both GPFS required significant additional silage imports $(1,917$ and $5,796 \mathrm{~kg}$ of $\mathrm{DM} / \mathrm{ha})$ to meet the winter feed requirements. When similar pasture productivity $(13,225 \mathrm{~kg}$ of $\mathrm{DM} / \mathrm{ha})$ and average silage conservation efficiency is considered (0.75; Bastiman and Altman, 1985), the additional feed required for dairy cows correspond to an additional external support land area requirement of 3.9 and 7.4 ha for HCFS and HOFS, respectively (and equivalent to an overall land area SR of 2.63 and 2.85 cows/ha, respectively).

Increasing SR traditionally results in reduced pasture DM intake and milk production but increased milk production per hectare (Macdonald et al., 2008; McCarthy et al., 2011). The use of supplementary feeds to maintain individual animal performance at higher GPSR is generally considered to reflect the commercial effect of SR increase on dairy farms where SR and supplementation usually increase simultaneously (Jensen et al., 2005). Previous studies have also observed a strong positive effect of higher levels of concentrate and forage supplementation during lactation on milk production characteristics when compared with pasture-only diets (McCarthy et al., 2007; Valentine et al., 2009; Fariña et al., 2011). Increased SR combined with increased concentrate supplementation (HOFS) within the current study created a similar CSR and level of pasture utilization and resulted in increased milk and milk fat plus protein production per cow and per hectare. Equally, the similarity of postgrazing residuals and grazing efficiency between HCFS and HOFS is also indicative of the efficient supplementation of the HOFS based on consistently matching supplementation rates to herd requirements.

Where pasture supply is sufficient to meet animal requirements, it is generally considered uneconomical to use supplements due to high pasture substitution rates and low milk production responses to supplementary feeding on grazing dairy farms (Bargo et al., 2003; Ramsbottom et al., 2015). In the current study, however, supplements were only offered to HOFS to alleviate shortfalls in herbage DMI by reducing pas- 
ture allowance and maintaining similar postgrazing residuals to HCFS. Similar to previous studies combining increased SR and increased supplementation (Coleman et al., 2010), a substantial increase in milk and milk fat plus protein production per hectare $(+56$ and $+55 \%$, respectively) was realized in HOFS. The overall increase in milk production corresponds to a systemic response of $1.40 \mathrm{~kg}$ of additional milk and $0.11 \mathrm{~kg}$ of additional fat plus protein per $\mathrm{kg}$ of additional feed used within the higher GPSR system. High systemic responses to supplementation have also previously been attributed to a reduced substitution rate of concentrate for herbage within restricted higher SR systems (Bargo et al., 2003).

The success of pasture-based dairy farms is dependent on maximizing productivity from pasture and output per hectare on the milking platform (Dillon et al., 2008; Macdonald et al., 2008). In comparison with milk productivity within typical grazing systems (763 $\mathrm{kg}$ of milk and fat plus protein/ha; Dillon et al., 2005), the results of this analysis demonstrate the capacity for increased milk fat plus protein productivity $(+151$ and $+234 \%$ for HCFS and HOFS, respectively) within both pasture-based systems. Moreover, the superior performance of the HOFS treatment indicates that, based on increased feed supplementation complemented with an increased SR to maintain a moderate pasture allowance, high levels of pasture utilization and efficient utilization of available feed resources can be achieved within pasture systems incorporating increased supplementary feed levels. Notwithstanding these benefits, further whole-farm research should be conducted to explore both the economic and environmental implications of such systems before recommendations can be made to pasture-based milk producers. These results also suggest that, in order for pasture-based dairy farmers to harness the benefit of the increased SR reported here, improved grazing management skills at farm level will be required with such intensified systems to further increase herbage utilization on commercial farms and minimize the requirement for imported feed supplementation to the levels reported in this study.

\section{CONCLUSIONS}

Access to adequate grazable area is a critical limitation to the productivity of grazing systems. To our knowledge, this is the first farmlet experiment to explore the effects of increased grazing area SR on both the productivity of pastures and animals and requirements for additional supplements within intensified grazing systems. The strategic use of additional supplements with restricted pasture availability combined to maintain production per cow at higher GPSR and significantly increase milk production per hectare. The results of the present study indicated that increasing GPSR had no effects on pasture production, utilization, and feed quality.

\section{ACKNOWLEDGMENTS}

We acknowledge the financial support of the Irish Dairy Levy, and we thank the staff of Ballyhaise College (Ballyhaise, Co. Cavan, Ireland) for their co-operation, care, and management of the experimental cows.

\section{REFERENCES}

Bargo, F., L. D. Muller, E. S. Kolver, and J. E. Delahoy. 2003. Invited review: Production and digestion of supplemented dairy cows on pasture. J. Dairy Sci. 86:1-42.

Bastiman, B., and J. F. B. Altman. 1985. Losses at various stages in silage making. Res. Development Agric. 2:19-25.

Baudracco, J., N. Lopez-Villalobos, C. W. Holmes, and K. A. Macdonald. 2010. Effects of stocking rate, supplementation, genetic strain and their interactions on grazing dairy systems: A review. N. Z. J. Agric. Res. 53:109-133.

Coleman, J., K. M. Pierce, D. P. Berry, A. Brennan, and B. Horan. 2010. Increasing milk solids production across lactation through genetic selection and intensive pasture-based feed system. J. Dairy Sci. 93:4302-4317.

Creighton, P., E. Kennedy, L. Shalloo, T. M. Boland, and M. O'Donovan. 2011. A survey analysis of grassland dairy farming in Ireland, investigating grassland management, technology adoption and sward renewal. Grass Forage Sci. 66:251-264.

del Corral, J., J. A. Perez, and D. Roibas. 2011. The impact of land fragmentation on milk production. J. Dairy Sci. 94:517-525.

Dillon, P., S. Crosse, G. Stakelum, and F. Flynn. 1995. The effect of calving date and stocking rate on the performance of springcalving dairy cows. Grass Forage Sci. 50:286-299.

Dillon, P., T. Hennessy, L. Shalloo, F. Thorne, and B. Horan. 2008. Future outlook for the Irish dairy industry: A study of international competitiveness, influence of international trade reform and requirement for change. Int. J. Dairy Technol. 61:16-29.

Dillon, P., J. R. Roche, L. Shalloo, and B. Horan. 2005. Optimising financial return from grazing in temperate pastures. Pages 131-147 in Utilization of Grazed Grass in Temporal Animal Systems. J. J. Murphy, ed. Wageningen Acad. Publ., Wageningen, the Netherlands.

Edmonson, A. J., I. J. Lean, L. D. Weaver, T. Farver, and G. Webster. 1989. A body condition scoring chart for Holstein dairy cows. J. Dairy Sci. 72:68-78.

Fariña, S. R., S. C. García, W. J. Fulkerson, and I. M. Barchia. 2011. Pasture-based dairy farm systems increasing milk production through stocking rate or milk yield per cow: Pasture and animal responses. Grass Forage Sci. 66:316-332.

Finneran, E., P. Crosson, M. Wallace, P. O'Kiely, D. Forristal, and L. Shalloo. 2010. Simulation modelling of the cost of producing and utilising feeds for ruminants on Irish farms. J. Farm Manage. 14:95-116.

Hoden, A., J. L. Peyraud, A. Muller, L. Delaby, and P. Faverdin. 1991. Simplified rotational grazing management of dairy cows: Effects of rates of stocking and concentrate. J. Agric. Sci. 116:417-428.

Horan, B., J. F. Mee, M. Rath, P. O'Connor, and P. Dillon. 2004. The effect of strain of Holstein-Friesian cow and feed system on reproductive performance in seasonal-calving milk production systems. Anim. Sci. 79:453-467.

Irish Cattle Breeding Federation (ICBF). 2009. Irish cattle breeding statistics 2009. Irish Cattle Breeding Society Limited, Shinagh House, Bandon, Co. Cork, Ireland. 
Jensen, R. N., D. A. Clark, and K. A. Macdonald. 2005. Resource efficient dairying trial: measurement criteria for farm systems over a range of resource use. Proc. New Zealand Grassland Assoc. $67: 47-52$.

Kellaway, R., and S. Porta. 1993. Feeding Concentrates: Supplements for Dairy Cows. R. Hopkins, ed. Agmedia, East Melbourne, Australia.

Kennedy, E., M. McEvoy, J. P. Murphy, and M. O'Donovan. 2009. Effect of restricted access time to pasture on dairy cow milk production grazing behavior, and dry matter intake. J. Dairy Sci. 92:168-176.

Läpple, D., T. Hennessy, and M. O'Donovan. 2012. Extended grazing: A detailed analysis of Irish dairy farms. J. Dairy Sci. 95:188-195.

Lee, J., D. J. Donaghy, and J. R. Roche. 2007. The effect of grazing severity and fertiliser application during winter on herbage regrowth and quality of perennial ryegrass (Lolium perenne L.). Aust. J. Exp. Agric. 47:825-832.

Macdonald, K. A., J. W. Penno, J. A. S. Lancaster, and J. R. Roche. 2008. Effect of stocking rate on pasture production, milk production and reproduction of dairy cows in pasture-based systems. J. Dairy Sci. 91:2151-2163.

McCarthy, B., L. Delaby, K. M. Pierce, F. Journot, and B. Horan. 2011. Meta-analysis of the impact of stocking rate on the productivity of pasture-based milk production systems. Animal 5:784-794.

McCarthy, B., K. M. Pierce, L. Delaby, A. Brennan, C. Fleming, and B. Horan. 2013. The effect of stocking rate and calving date on grass production, utilization and nutritive value of the sward during the grazing season. Grass Forage Sci. 68:364-377.

McCarthy, S., B. Horan, P. Dillon, P. O'Connor, M. Rath, and L. Shalloo. 2007. Economic comparison of divergent strains of Holstein-Friesian cows in various pasture-based production systems. J. Dairy Sci. 90:1493-1505.

Morgan, D. J., G. Stakelum, and J. Dwyer. 1989. Modified neutral detergent cellulase digestibility procedure for use with the 'Fibertec' system. Isr. J. Agric. Res. 28:91-92.
National Farm Survey (NFS). 2014. Teagasc, Athenry, Ireland.

O'Donnell, S., L. Shalloo, A. M. Butler, and B. Horan. 2008. A survey analysis of opportunities and limitations of Irish dairy farmers. J. Farm Manage. 13:1-15.

Patton, D., L. Shalloo, K. M. Pierce, and B. Horan. 2012. A biological and economic comparison of 2 pasture-based production systems on a wetland drumlin soil in the northern region of Ireland. J. Dairy Sci. 95:484-495

Plaizier, J. C., D. O. Krause, G. N. Gozho, and B. W. McBride. 2008. Subacute ruminal acidosis in dairy cows: The physiological causes, incidence and consequences. Vet. J. 176:21-31.

Ramsbottom, G., B. Horan, D. P. Berry, and J. R. Roche. 2015. Factors associated with the financial performance of spring-calving, pasture-based dairy farms. J. Dairy Sci. 98:3526-3540.

Shalloo, L., P. Dillon, J. O'Loughlin, M. Rath, and M. Wallace. 2004 Comparison of a pasture-based system of milk production on a high rainfall, heavy-clay soil with that on a lower rainfall, freedraining soil. Grass Forage Sci. 59:157-168.

Sollenberger, L. E., and E. S. Vanzant. 2011. Interrelationships among forage nutritive value and quantity and individual animal performance. Crop Sci. 51:420-432.

SAS Institute Inc. 2006. Users Guide: Statistics. Version 9.3. SAS Institute Inc., Cary, NC.

Tyrrell, H. F., and J. T. Reid. 1965. Prediction of the energy value of cows' milk. J. Dairy Sci. 48:1215-1223.

Valentine, S., P. Lewis, R. T. Cowan, and J. Defaveri. 2009. The effects of high stocking rates on milk production from dryland and irrigated Mediterranean pastures. Anim. Prod. Sci. 49:100-111.

Van Soest, P. J. 1963. Use of detergents in the analysis of fibrous feeds. II. A rapid method for the determination of fiber and lignin. J. AOAC 46:829-835. 